relation especially to the definition, expansion, or movement of the margins of major arid regions such as the Sahara. Much of the key to this fascinating problem may well lie hidden in the ancient Saharan erg and other sand accumulations of the desert fringes.

\section{Injury-feigning Behaviour of Wood-pigeons}

DESCRIBed as infrequent in the Handbook of British Birds, two apparently related cases of injuryfeigning among wood-pigeons (Columba palumbus) have been recorded by C. S. Payne (The Bedfordshire Naturalist, 12 ; 1959). Disturbed by a pointer dog in Kempton Park, a wood-pigeon flew straight over the grass at a height of only $1 \mathrm{ft}$. from the ground, in a manner similar to that of a common sandpiper flying over water. Near the dog was a fully grown and feathered young pigeon which had presumably fallen to the ground before it could fly. Six days later the dog again disturbed an adult wood-pigeon which was "floundering along in the grass as if it had no legs, and progressing a few inches at a time, very awkwardly, by means of its wings". When Payne attempted to pick the bird up it rose buoyantly into the air and flew away. On this occasion no young bird was found. This may have been the same adult which had previously been observed, the distraction behaviour of which had been retained.

\section{Urwick Medal for Management Studies}

The Polytechnic Management Association has instituted a new annual award, to be known as the Urwick Medal, for presentation to the best final-year student in the diploma course in management studies at the Regent Street Polytechnic, London. The first award will be made at the end of the session $1958-59$. The Association's members are past and present students of management at the Polytechnic.

\section{Royal Society of Tasmania : Officers}

THE following were recently elected to office in the Royal Society of Tasmania for the year 1959: President, The Governor of Tasmania; Vice-Presidents, Mr. L. W. Miller, Dr. D. Martin; Council, Hon. Mr. Justice Crisp, Mr. R. M. H. Garvie, Ir. E. Guiler, Mr. K. D. Nicolls, Mr. M. S. R. Sharland, Mr. J. W. C. Wyett, Mr. W. F. Ellis, Mr. G. H. Stancombe; Hon. Treasurer, Mr. G. E. A. Hale; Hon. Auditor, Mr. A. M. Hewer; Hon. Secretary and Librarian, Dr. W. Bryden; Librarian, Miss E. M. Geddes.

\section{Harwell Reactor School Courses}

EIgHTEEN standard or full courses have to date been held at the Harwell Reactor School, and Standard Course No. 19 will start on August 3I, and continue until December 18. Altogether, 951 students from 32 different countries have so far attended these courses, which began in September 1954 and are designed to train engineers in the techniques of reactor construction and operation, particularly in connexion with nuclear power stations. Half the places at each course are allocated to overseas students, and a fee of $\$ 250$ exclusive of accommodation is charged. A special course for senior technical executives will be held during September 21-October 1. This is the ninth course of this kind and the fee is fifty guineas exclusive of accommodation. Application forms and details of both courses can bo obtained from The Principal, Reactor School, Atomic Energy Research Establishment, Harwell, Didcot, Berks.

\section{Announcements}

Prof. J. A. L. Matheson, Beyer professor of engineering in the University of Manchester, has been appointed as the first vice-chancellor of the new Monash University, Melbourne.

Prof. N. J. Petch, professor of metallurgy in the University of Leeds, has been appointed to the chair of metallurgy at King's College, Newcastle upon Tyne. For a note on the work of Prof. Petch see Nature, 178, 347 (1956).

Mr. A. L. Bacharach has been elected president of the Nutrition Society in succession to Dame Harriette Chick. Prof. R. G. Baskett, Mr. F. le Gros Clark, Dr. H. N. Munro and Dr. F. Yates were elected ordinary members of Council. Dr. R. J. L. Allen (Beecham Foods, Ltd., Brentford, Middlesex) is honorary secretary.

The Oliver Bird Prize for 1958 has been awarded to Prof. M. C. Shelesnyak of the Weizmann Institute of Science, Israel, in recognition of his work on the role of histamine in the decidual response of the endometrium and the discovery that ovum-implantation can be suppressed by the presence of histamine antagonists in the uterus before nidation.

A conference on Co-operative Phenomena and Phase Transitions, organized by Prof. G. S. Rushbrooke on behalf of the Physical Society, will be held at Kings College, Newcastle upon Tyne, during July 6-7. There will be four sessions, devoted to : thermodynamics and phenomenology; melting and liquids; quantal fluids; and lattice interactions (Ising and Heisenberg models). Further details may be obtained from Miss E. Miles, Physical Society, 1, Lowther Gardens, Prince Consort Road, London, S.W.7.

The ninth Canadian High Polymer Forum will be held at the Guild Inn, Toronto, Ontario, during October 26-28. The Forum is sponsored by the National Research Council of Canada in co-operation with the Chemical Institute of Canada, and is devoted to all aspects of polymer science. Authors wishing to submit papers for presentation at the Forum should write to the programme chairman, Dr. L. A. MeLeod, Research and Development Division, Polymer Corporation Ltd., Sarnia, Ontario, Canada. Titles and abstracts of approximately 300 words will be required by August 1. General information concerning the Forum can be obtained from Dr. M. H. Jones, chairman, Ninth Canadian High Polymer Forum, Ontario Research Foundation, 43 Queen's Park, Toronto 5, Ontario.

THE Australian Branch of the Institute of Physics will hold a Conforence on Solid State Physics in Melbourne during August 17-22. Some forty physicists from Australia, four from New Zealand, ten from the United States, about five from the United Kingdom, and two from Canada will read papers on original work. The papers offered fall mainly into the fields of lattice and electron theory of metals, low-temperature physics, imperfections and plastic deformation, erystal growth, and surface phenomena. Other fields of solid state physics will also be discussed. Further information can be obtained from the convener, Dr. W. Boas, Division of Tribophysics, Commonwealth Scientific and Industrial Research Organization, University of Melbourne, Carlton, N.3, Victoria, Australia. 